Journal of Money and Economy

Vol. 15, No. 2, Spring 2020

pp. 181-197

DOI: 10.2952/jme.15.2.181

Original Research Article

\title{
Does One Size Fit All? The Impact of Liquidity Requirements on Bank's Insolvency: Evidence from Iranian Listed Banks
}

\author{
Vahideh Sotoudeh Mollashahi" \\ Mohammad Ali Rastegar*
}

\author{
Mohammad Talebi ${ }^{\dagger}$ \\ Ramin Mojab
}

Received: 19 Sep 2020

Approved: 28 Dec 2020

According to the Basel III regulatory framework, uniform minimum liquidity requirements have been imposed on all types of banks. Using an agent-based model of a banking system, we investigate the effects of liquidity requirements on banks' insolvency under two policy experiments in one of which the minimum liquidity requirements are applied uniformly and in the other differentially across banks. The model introduces a banking system with 12 heterogeneous banks that must also comply with two liquidity requirements while performing their daily activities of taking deposits and making loans. The model is applied to the Iranian banking system. Results illustrate that because banks respond differently to liquidity requirements, applying one size minimum liquidity requirements to all kinds of banks, strengthens the likelihood of a liquidity shock turns into banks' insolvency and could increase banking system instability. Thus our findings highlight that to achieve financial stability at the national level, policymakers should revise the current one size fits all approach when designing liquidity requirements.

Keywords: Liquidity Requirement, Solvency Requirement, Agent-Based Models. JEL Classification: C63, G21, G28

\footnotetext{
* Monetary and Banking Research Institute, Central Bank of the Islamic Republic of Iran, Tehran, Iran; vahidesotoudeh@gmail.com (Corresponding Author)

$\dagger$ Department of Financial Management, Imam Sadegh University, Tehran, Iran

¥ School of Industrial and Systems Engineering, Tarbiat Modares University, Tehran, Iran

$\S$ Monetary and Banking Research Institute, Central Bank of the Islamic Republic of Iran, Tehran, Iran
}

** This paper is an outcome of the Ph.D. thesis written by $1^{\text {st }}$ author and supervised by $2^{\text {nd }}$ author and advised by $3^{\text {rd }}$, and $4^{\text {th }}$ authors at the Monetary and Banking Research Institute, Central Bank of the Islamic Republic of Iran. 


\section{Introduction}

Liquidity requirements can affect banks through several channels. Liquidity requirements could reduce likelihood of bank insolvency followed by liquidity shocks (BCBS, 2016). However, one problem with the Basel III minimum liquidity requirement is that unequal banks regarding size and business model are regulated the same (Grossmann, 2019).

This paper presents a model that focuses on minimum liquidity requirements and their interaction with banks' solvency position. The model's primary purpose is to assess banks' insolvency under two policy experiments in which the minimum liquidity requirements are applied uniformly and differentially across banks to find out which policy is more efficient in terms of the lower insolvency rate of each bank and the banking system as a whole.

The banking system is complex since banks interact with customers, firms, and each other. These interactions are influenced by human decision-making and include feedback from economic and financial systems. One approach to examining financial risk and related policies is agent-based modeling (ABM), which uses a bottom-up approach of learning adaptive heterogeneous agents (Farmer and Foley, 2009).

Agent-based modeling (ABM) is appropriate for studying complex systems and is a robust technique to assess system-level patterns that emerge from autonomous agents' actions and interactions.

To take into account the interaction between banks, we used an agent-based modeling approach. Agent-based modeling has been used to model banks' behavior as individual agents, and interactions of agents that could reproduce complex properties of the system. ABM models are useful for analyzing risks in financial systems and evaluating different policies (Bookstaber, 2012)

Distinguin et al. (2013) were among the first to discuss uniform liquidity requirements for all types of banks. They use simultaneous equations method and study the relationship between bank regulatory capital and bank liquidity measured from on-balance sheet positions for European and U.S. publicly traded commercial banks. According to their results small banks improve their solvency position when they are exposed to higher illiquidity. Their findings stress the need to implement minimum liquidity ratios compatible to capital ratios; however, their findings underscore the need to further explain how to regulate large banks that are different from small banks.

Similar to our paper, Neuberger and Rissi (2014) use the agent-based modeling to analyze the impact of both financial system architecture and financial market participants' behavior on financial stability and the 
effectiveness of macroprudential policies. Based on the results of their paper, imposing indirect restrictions through liquidity, leverage and capital regulations has less effect than direct restrictions through the bank's investment portfolio.Using data from the Swiss financial system in their model, they concluded that the more complex the regulation, the more destabilizing effects it would have on the system.

Birindelli et al. (2016) investigate the effect of Basel III requirements on the stability of banks working under different business models using a sample of Eurozone banks classified into six business models over the period 20012014. According to their finding, it is necessary to revise the current "onesize-fits-all" prudential framework.

Aldasoro et al. (2017) further show that differential increases in liquidity coverage ratios based on banks' systemic importance improve the stability of system. They build a network model of optimizing banks featuring contagion on both sides of banks' balance sheets. They use simulated method of moments method to calibrate their model to the network of large European banks. The model has been used to study the effects of step-by- step increases in liquidity coverage ratios.

Gorssmann (2019), takes into account the differences between retail, wholesale, and trading banks to examin whether diverse but internationally harmonized capital and liquidity requirements for business models in Pillar 1 of the Basel framework are helpful and how they can be applied. His findings show that business models are affected differently by higher capital requirements.

In literature related to analyzing the effectiveness of macroprudential policies, especially liquidity, and capital requirement, the impact of bank' size (Distinguin et al., 2013), business model (Birindelli et al., 2016; Gorssmann 2019), systemic importance (Aldasoro et al., 2017) and financial system architecture (Neuberger and Rissi, 2014) has been investigated. However, no research focuses on banks' differences in terms of liquidity and insolvency risk. We close this gap by introducing an agent model of the banking system in which we focus on banks with different liquidity and capital positions.

The organization of the remainder of the paper is the following. Section 2 presents model dynamics. Section 3 describes the parameters and initial value of variables, and Section 4 illustrates the use of the platform to perform policy experiments. Finally, section 5 concludes by discussing the policy implications of the model. 


\section{The Model}

The paper of Smaga et al. 2018 and Georg 2013 have been used to build the model. In our model, there are 12 heterogeneous banks that, while performing their traditional business activities of taking deposits and making loans to firms and households, must also comply with the regulator's liquidity requirements. Suppose a bank finds itself unable to meet liquidity requirements. In that case, it can satisfy its liquidity needs through the interbank market, the sale of securities, and finally borrowing from the central bank if the interbank market and security market funding sources were not sufficient. The actions that a bank performs to meet its liquidity needs have interest costs that can deteriorate net interest income and, consequently, the bank's capital positions. Therefore, in this model, liquidity shock can lead to insolvency of the banks. Since we would like to analyze the banks' insolvency caused by the liquidity shock, our model focuses on the short term and updates daily. It is assumed that the interbank market only includes overnight loans (unsecured). This assumption is not far from reality because more than $90 \%$ of interbank transactions in the Iranian interbank market are overnight loans ${ }^{1}$.

Banks in the model are heterogeneous with respect to their size (initial value of balance sheet items) and parameters related to their liquidity and capital positions.

The banking system is made up of 12 banks. Table 1 presents the balance sheet of bank i. On the asset side, a bank can hold cash $C_{t}^{i}$ as a high-quality liquid asset, make loans to firms and households $L_{t}^{i}$, invest in security $S_{t}^{i}$, lend to other banks in the interbank market $I L_{t}^{i}$. These assets can be funded by deposit $D_{t}^{i}$, equity $E_{t}^{i}$, borrowing from the interbank market $I L_{t}^{i}$, and central bank $C L_{t}^{i}$.

The balance sheet items in our model change endogenously by the daily activities that a bank performs. Figure 1 illustrates the different actions a bank takes and its interaction with the other banks through the interbank market.

First, bank i holds assets and has liabilities from the end of the previous day (In day 0, the bank endowed with initial values), then the bank does its daily activities as follow:

\footnotetext{
${ }^{1}$ According to the Central Bank of Islamic Republic of Iran reports on the overall performance of the interbank market in Rials.
} 
Table1

Balance sheet items of a representative bank

\begin{tabular}{cc}
\hline Assets & Liabilities \\
\hline$C_{t}^{i}$ & $D_{t}^{i}$ \\
$L_{t}^{i}$ & $E_{t}^{i}$ \\
$S_{t}^{i}$ & $I L_{t}^{i *}$ \\
& $C L_{t}^{i}$ \\
\hline
\end{tabular}

* When $I L_{t}^{i}$ is negative (positive), it indicates interbank borrowing (lending).

- To obtain interest for the loan $r^{l}$ and pay interest on deposits $r^{d}$

- To payback some of the loans to the costumers and make some new loans (the amount of banks' loans change by $\Delta L_{t}^{i}$ ).

- To receive further deposits from the households and/or suffer deposit withdrawing (the amount of banks' deposit change by $\Delta D_{t}^{i}$ ).

- All interbank loans $I L_{t-1}^{i}$ plus interests (the interest rate for the interbank loans is $r^{i n}$ ) are paid either to or by bank $i$.

- Central bank loans $C L_{t-1}^{i}$ plus interests (the interest rate for the central bank loan is $r^{c}$ ) are paid by bank $\mathrm{i}$.

- The bank has to hold a certain fraction of the deposit $\beta D_{t}^{i}$ as required reserves at the central bank

Afterward, the bank calculates its liquidity $C_{t}^{i}$ and checks whether it has satisfied liquidity requirements:

$C_{t}^{i}=C_{t-1}^{i}+\beta D_{t-1}^{i}-r^{d}+r^{l}+\left(1+r^{i n}\right) I L_{t-1}^{i}+\left(1+r^{c}\right) C L_{t-1}^{i}+\Delta D_{t}^{i}+$ $\Delta L_{t}^{i}$

In our model, there are two liquidity requirements that banks should comply with. One of which is the Reserve Requirement (RR) $\beta D_{t}^{i}$ that is an obligatory level of bank cash set aside daily. The other is the liquidity coverage ratio (LCR), which is calculated on a monthly basis and should be more than the regulatory level imposed by policymakers $S L C R$.

Eq. (3) is the model representation of LCR. The numerator consists of the stock of high-quality liquid assets, which is referred to as cash and securities in our model. The denominator is the total net deposit outflows over the next 30 calendar days. $\delta$ is the probability of deposit outflows over the next 30 calendar days. 


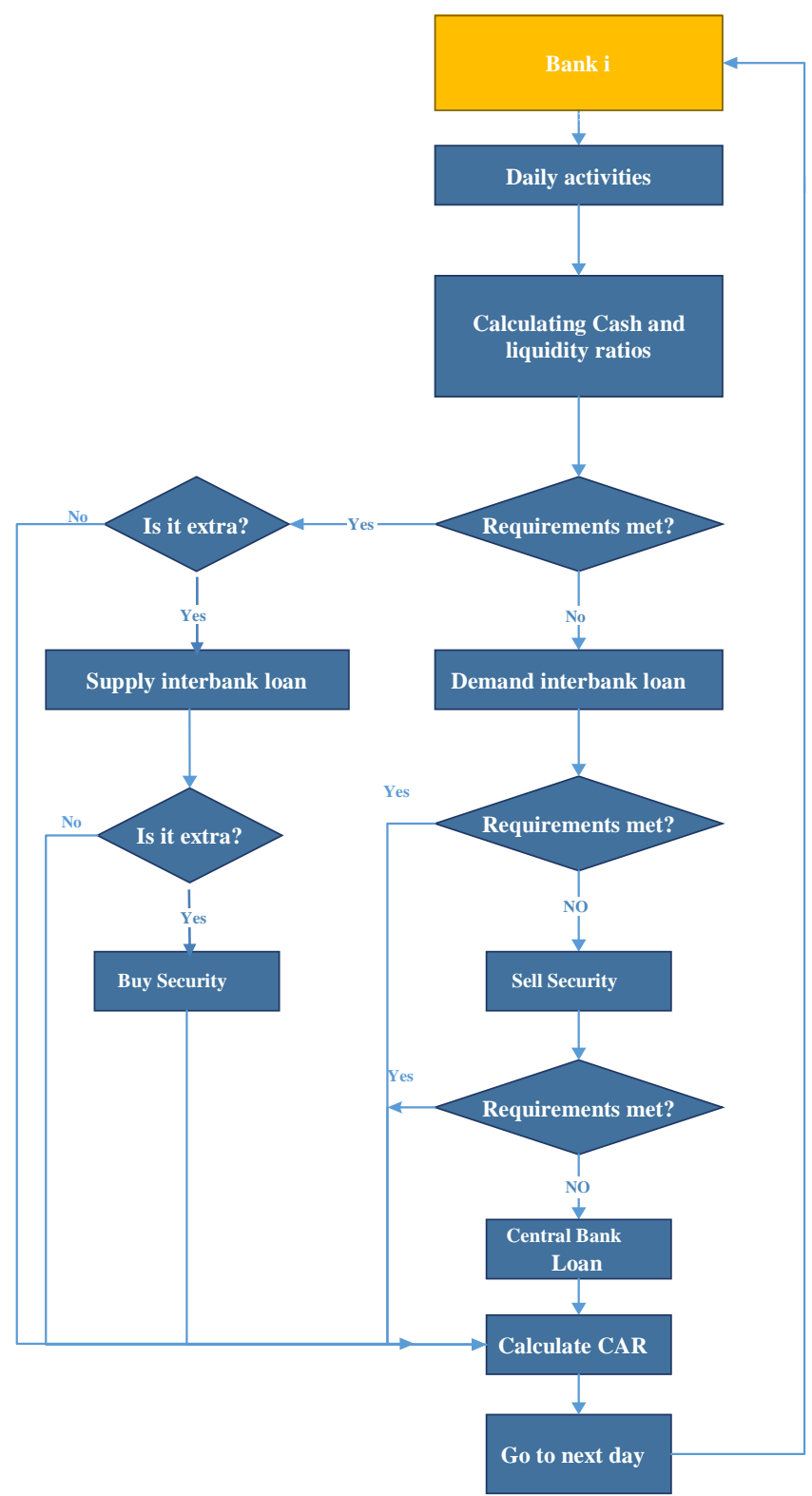

Figure 1. Banks Daily Activities. 
$R R: C_{t}^{i} \geq \beta D_{t}^{i}$

$L C R: \frac{C_{t}^{i}+S_{t-1}^{i}}{\delta D_{t}^{i}} \geq S L C R$

If two requirements have been satisfied by bank $i$, the bank is dealing with a cash surplus and can allocate the remaining excess of cash on the interbank market. If the bank is dealing with a cash deficit (does not satisfy RR or $S L C R$ ), the bank tries to borrow the amount needed from other banks in the interbank market to fulfill these two requirements.

Because the RR must be observed on a daily basis and the $L C R$ must be observed on a monthly basis, except for the last day of each month, the bank's liquidity demand or supply $D I L_{t}^{i}$ is given as:

$D I L_{t}^{i}=$

$\begin{cases}\min \left(C_{t}^{i}-\beta D_{t}^{i}, C_{t}^{i}+S_{t-1}^{i}-\delta D_{t}^{i} * S L C R\right) & \text { if } t=20,40 \text { and } 60 \\ C_{t}^{i}-\beta D_{t}^{i} & \text { otherwise }\end{cases}$

So the demand for the interbank loan, which depends on the liquidity situation of the bank i at time t, can be positive (lending to other banks) or negative (borrowing from other banks).

If bank i has liquidity demand, it will go to the interbank market and asks all bank $\mathrm{j}$ randomly whether they have a liquidity surplus. If this is the case, bank i can receive an interbank loan from Bank j.

If bank i has a liquidity supply, it will go to the interbank market and asks all bank $\mathrm{j}$ randomly whether they have a liquidity deficit. If this is the case, bank i can make an interbank loan to Bank j.

Depending on the situation of other banks, sometimes there is not enough demand for the cash supplied by bank i, in the interbank market, or funds supplied by other banks is not enough to cover the bank's cash deficit. Therefore the interbank loan can be obtained via Eq. (5):

$I L_{t}^{i}=\min \left\{\begin{array}{ccc}D I L_{t}^{i},-\sum_{j: i} D I L_{t}^{j} \mid D I L_{t}^{j} . D I L_{t}^{i}<0 ; & \text { if } \quad D I L_{t}^{i}>0 \\ -D I L_{t}^{i}, \sum_{j: i} D I L_{t}^{j} \mid D I L_{t}^{j} . D I L_{t}^{i}<0 ; & \text { if } \quad D I L_{t}^{i}<0\end{array}\right\}$

Georg (2013) introduced this rationing mechanism. $\mathrm{j}$ : i stands for all bank $\mathrm{j}$ that connected to $\mathrm{i}$.

After the interbank market transactions, bank i may still do not satisfy two liquidity requirements. If this is the case, it must sell securities to the extent that its liquidity shortage is covered. Or on the other hand, it may face a cash 
surplus, so it uses that to buy securities. The banks are not only participants in the securities market, and their activities could change the price of securities, but for simplicity, we assume that banks' supply and demand could not influence the price of securities. The value of securities which a bank needs to buy or sell $S N_{t}^{i}$ is obtained from the following equation:

$S N_{t}^{i}=D I L_{t}^{i}-I L_{t}^{i}$

If $S N_{t}^{i}$ is negative, the bank needs to sell securities, and if it is positive, the bank has a demand to buy securities.

So the security demand for each bank $S D_{t}^{i}$ is:

$S D_{t}^{i}=\max \left(S N_{t}^{i},-S_{t-1}^{i}\right)$

This phrase states that the bank cannot sell more securities than the value of its securities. It is also assumed that the bank can buy as many securities from the market as it needs.

The securities' value of bank i after selling or buying securities is given as:

$S_{t}^{i}=S_{t-1}^{i}+S D_{t}^{i}$

When bank i still has a liquidity demand, it can ask for a central bank loan:

$C L_{t}^{i}=S N_{t}^{i}-S D_{t}^{i}$

At the end of the day, the equity of bank $i$ is as follow:

$E_{t}^{i}=E_{t-1}^{i}+r^{l}-r^{d}+r^{i n} I L_{t-1}^{i}+r^{c} C L_{t-1}^{i}$

The capital adequacy of banks simply is calculated as follow:

$C A R=\frac{E_{t}^{i}}{L_{t}^{i}}$

These steps are done for 60 working days. 


\section{Data and Simulation}

This section provides a brief overview of the data and simulation exercise aimed at analyzing the impact of the liquidity requirements on solvency positions of banks under two policy experiments (uniform and different minimum liquidity requirements across banks).

- There are 12 banks (The number of banks was chosen according to 12 listed Iranian banks).

- The analysis focuses on quarterly data of capital adequacy ratio, so the number of update steps was chosen to be 60 working days, approximately three months.

- Every simulation was repeated 500 times.

- Interest for loan $r^{l}$, interest on deposits $r^{d}$, loans changes $\Delta L_{t}^{i}$, deposit changes $\Delta D_{t}^{i}$ for each bank are random variables with normal distributions, calculated using 12 listed Iranian banks' monthly data.

- The initial value of balance sheet items have been chosen according to the balance sheet data of 12 banks (March 2018)

- The required reserve rate is $\beta=0.1$.

- The interbank rate was chosen to be $r^{\text {in }}=0.19$, according to the annual weighted average interbank rate in Iran at (2018-2019).

- The central bank loan interest rate $r^{c}=0.34$, which resembles the situation in the Iranian banking system at (2018-2019).

\section{Main Findings}

We conduct two policy experiments using generated banking systems to understand which policy is more efficient in terms of lower insolvency rate: uniform or different minimum liquidity requirements across banks?

\subsection{Uniform SLCR Policy}

As mentioned before, according to the macroprudential regulatory framework of Basel III, all banks around the world have to comply with the same minimum liquidity requirements to ensure the global competitiveness of banks. In this section, we want to examine each bank's reactions and the system as a whole to this policy. In this paper, the minimum liquidity requirements are defined as SLCR, which indicates the regulatory level of LCR imposed by policymakers, and the LCR of each bank must be at least equivalent to the SLCR.

Figure 2 shows the insolvency rate (percent), when all banks should satisfy the same minimum liquidity requirement, under 500 simulation runs. We 
simulate different SLCR ranging from SLCR $=0$ to $\mathrm{SLCR}=1$. As can be seen in the figure, banks' responses to the different SLCR are heterogeneous. Some banks, such as banks 2 and 9, are better off by increasing the SLCR since the insolvency rate decreases. According to the table of initial values (Appendix 1), on the one hand, these banks' capital positions are declining because their interest income is less than interest expenses. On the other hand, their liquidity situation deteriorates because cash inflow is less than the outflow. Therefore, it can be concluded that banks with high liquidity risk and, at the same time, high insolvency risk should be subject to stricter liquidity requirements.

Also, the capital positions of these banks improved in response to imposing tighter liquidity requirements. This could suggest that capital and liquidity requirements are, to some extent, substitutes.

However, for banks with good liquidity situations like 3,5 , and 8 that have an unfavorable capital position, increasing the SLCR does not change the insolvency rate. For SLCR, more than 0.8, the rate of the bank's insolvency increases. This, in turn, would indicate that liquidity requirement could only reduce the likelihood of bank insolvency caused by liquidity shocks, not all kinds of bank insolvencies.

And in banks with adequate liquidity and capital situation like 1, 4, 6, 7, 10,11 , and 12, the bank's insolvency rate increases by increasing the SLCR. This implies that these banks will see the rise of SLCR as a negative liquidity shock, and eventually, their capital adequacy ratio will worsen.

These findings imply that each bank reacts to SLCR differently; hence imposing the same liquidity requirements for all types of banks could be an inefficient policy. 


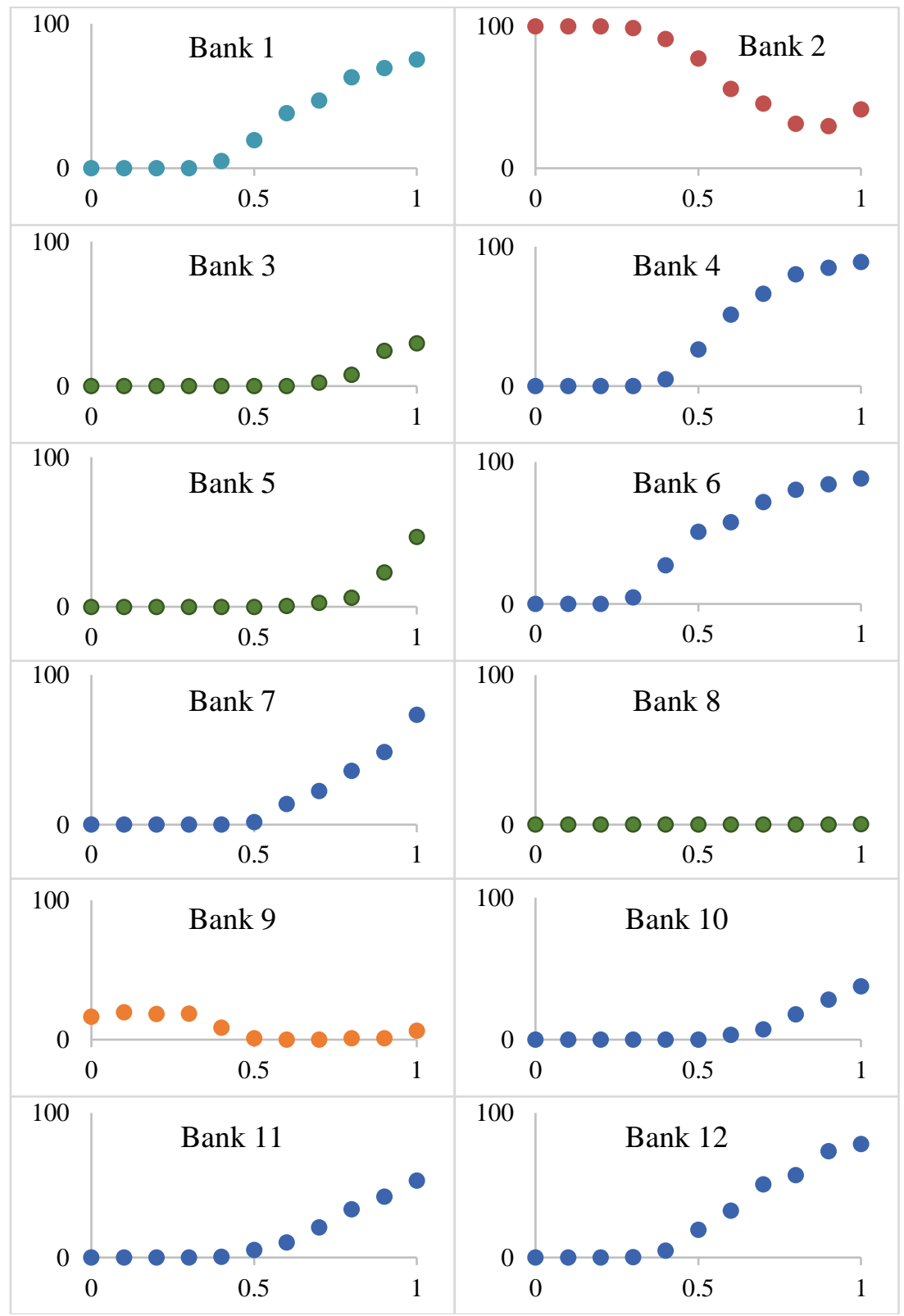

Figure 2. Insolvency Rate (Vertical Axis) for Different SLCR Values Ranging From 0 to 1 (Horizontal Axis)

Source: research computation 
Figure 3 shows the insolvency rate of the banking system for different SLCR values. As can be seen in the figure, the higher the SLCR, the more the insolvency rate. This figure indicates that $S L C R=0$ would be the best uniform policy regarding the minimum insolvency rate.

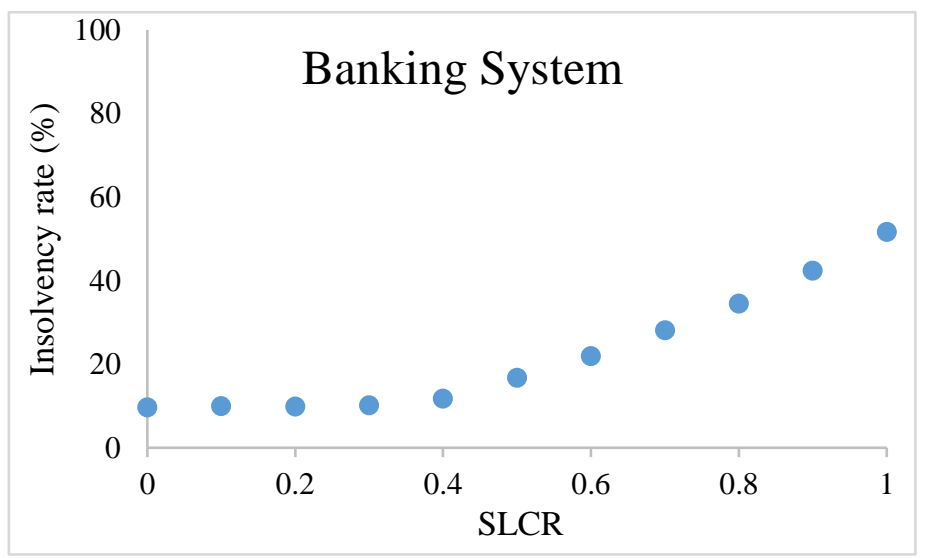

Figure 3. Insolvency Rate of the Banking System for Different SLCR Values. Source: research computation

\subsection{Different SLCR Policy}

In this section, we want to examine whether there is any situation in which policymakers impose different SLCR values for each bank, which is consistent with its liquidity and capital position. And whether the insolvency rate in the system as a whole is lower than the uniform situation.

Since there are 12 banks, and for each bank, there are 11 different values for SLCR $(0,0.1,0.2, \ldots, 1)$, the total number of cases is very large. So, we examine different cases to find at least one case with a lower insolvency rate than the uniform SLCR policy.

Since in the previous section, we show that in a uniform strategy, the best case in terms of low insolvency rate is $\mathrm{SLCR}=0$. We found at least one case in which each bank has to comply with different SLCR (see table 2 for SLCR values of banks), and the insolvency rate is lower than the uniform strategy of $\mathrm{SLCR}=0$. Figure 4 shows the distribution of the number of times of the banking system's insolvency rate in two uniform and different strategies. As shown in the figure, the insolvency rate is lower in the strategy that SLCR is defined differently for each bank. 
Information on the SLCR of each bank in a different SLCR strategy is given in Table 2. Interestingly, the table results show that only non-zero SLCR should be defined for banks that their liquidity situation is not favorable.

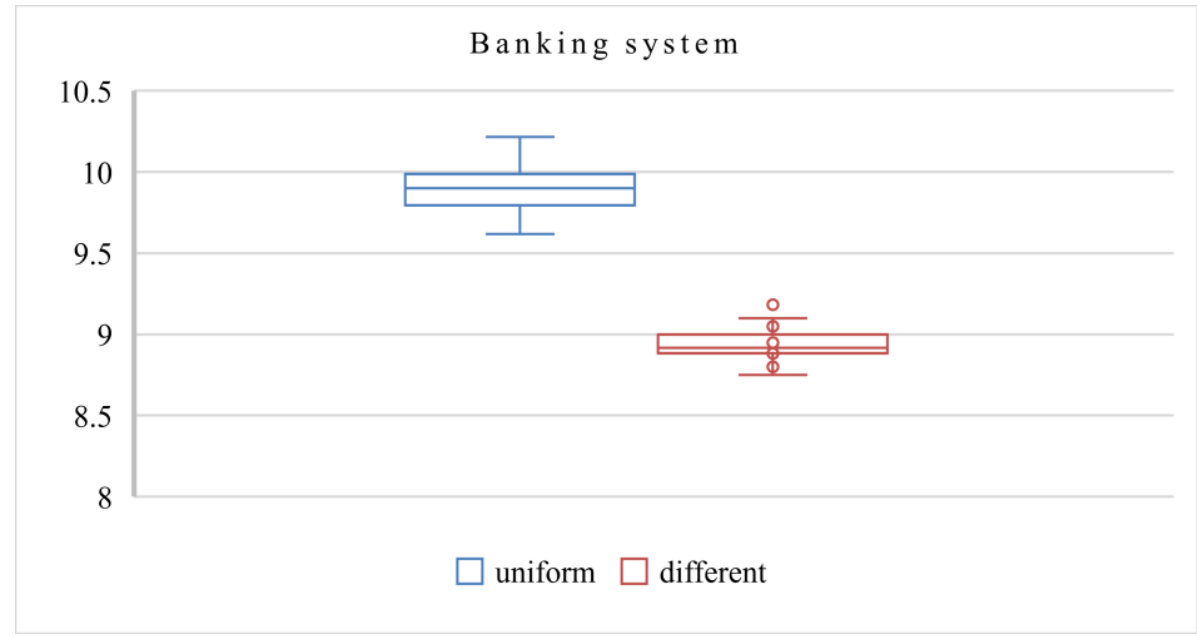

Figure 4. Insolvency Rate (percent) Distribution of the Banking System in Uniform and Different SLCR Policies.

Source: research computation.

Table 2

SLCR value for each bank in a different SLCR policy

\begin{tabular}{|c|c|c|c|c|c|c|c|c|c|c|c|c|c|}
\hline bank & & 1 & 2 & 3 & 4 & 5 & 6 & 7 & 8 & 9 & 10 & 11 & 12 \\
\hline$\overline{\text { SLCR }}$ & uniform & 0 & 0 & $\overline{0}$ & 0 & $\overline{0}$ & 0 & 0 & 0 & 0 & 0 & 0 & $\overline{0}$ \\
\hline value & different & 0 & 1 & 0.5 & 0 & 0.5 & 0 & 0 & 0 & 0.5 & 0 & 0 & 0 \\
\hline
\end{tabular}

Source: research computation

\section{Conclusion}

This paper uses an agent-based model of a banking system to examine which policy is more efficient, uniform, or different minimum liquidity requirements across banks regarding the effects of liquidity shock on banks' insolvency.

The findings show that A) banks' reaction to liquidity requirement is different and related to their liquidity and capital position; B) banks with high liquidity risk and, at the same time, high insolvency risk better off by imposing stricter liquidity requirements. The capital positions of these banks improved in response to imposing tighter liquidity requirements. This would suggest that 
capital and liquidity requirements are, to some extent, substitutes; C) imposing stricter liquidity requirements on banks with a sound liquidity situation; still, an unfavorable capital position has no significant effects on their insolvency rate. This would indicate that liquidity requirement could only reduce the likelihood of banks' insolvencies caused by liquidity shocks, not all kinds of banks' insolvencies. D) if banks with adequate liquidity and capital situation are subject to strict liquidity requirements, the bank's insolvency rate would increase since these banks consider the strict liquidity requirements as a negative liquidity shock. E) According to the Iranian banking system's data, the best uniform liquidity requirement in terms of low insolvency rate is the LCR to be Zero. However, we have found at least one combination of SLCR (table 2) in which the insolvency rate of the banking system is less than the uniform policy. This combination implies that policymakers should consider banks' capital and liquidity position when designing capital and liquidity requirements.

These findings are consistent with Neuberger and Rissi (2014) and David Gorbmann (2019), which mentioned that asking all banks to comply with the same requirement regardless of whether their business model is high-risk or low-risk and economic structure is not an efficient policy.

We assessed two policy experiments to find which policy is more efficient, uniform, or different minimum liquidity requirements across banks with respect to the effects of liquidity shock on banks' insolvency. However, liquidity and solvency are two interrelated concepts, and solvency can affect banks' liquidity positions. It would then be of interest to study the efficiency of two policies under the situation in which both liquidity and solvency are chosen simultaneously. We leave this for future research.

\section{References}

Aldasoro, I., Gatti, D. D., \& Faia, E. (2017). Bank Networks: Contagion, Systemic Risk and Prudential Policy. Journal of Economic Behavior \& Organization, 142, 164-188.

BCBS (2016). Literature Review on Integration of Regulatory Capital and Liquidity Instruments, BCBS Working Paper 30.

Birindelli, G., Ferretti, P., \& Savioli, M. (2016). Basel 3: Does One Size Really Fit All Banks' Business Models? (No. 16-20).

Bookstaber, R. (2012). Using Agent-Based Models for Analyzing Threats to Financial Stability. Office of Financial Research, Working Paper No, 0003 (U.S. Department of the Treasury). 
Distinguin, I., Roulet, C., \& Tarazi, A. (2013). Bank Regulatory Capital and Liquidity: Evidence From US and European Publicly Traded Banks. Journal of Banking \& Finance, 37(9), 3295-3317.

Farmer, J. D., \& Foley, D. (2009). The Economy Needs Agent-Based Modelling. Nature, 460(7256), 685-686.

Georg, C. P. (2013). The Effect of the Interbank Network Structure on Contagion and Common Shocks. Journal of Banking \& Finance, 37(7), 2216-2228.

Grossmann, D. (2019). Bank Regulation: One Size Does Not Fit All (Doctoral dissertation, Andrássy Gyula Budapesti Német Nyelvü Egyetem).

Neuberger, D., \& Rissi, R. (2012). Macroprudential Banking Regulation: Does One Size Fit All? Thu "nen-Series of Applied Economic Theory Working Paper, (124).

Smaga, P., Wiliński, M., Ochnicki, P., Arendarski, P., \& Gubiec, T. (2018). Can Banks Default Overnight? Modelling Endogenous Contagion on the $\mathrm{O} / \mathrm{N}$ Interbank Market. Quantitative Finance, 18(11), 1815-1829. 


\section{Appendix}

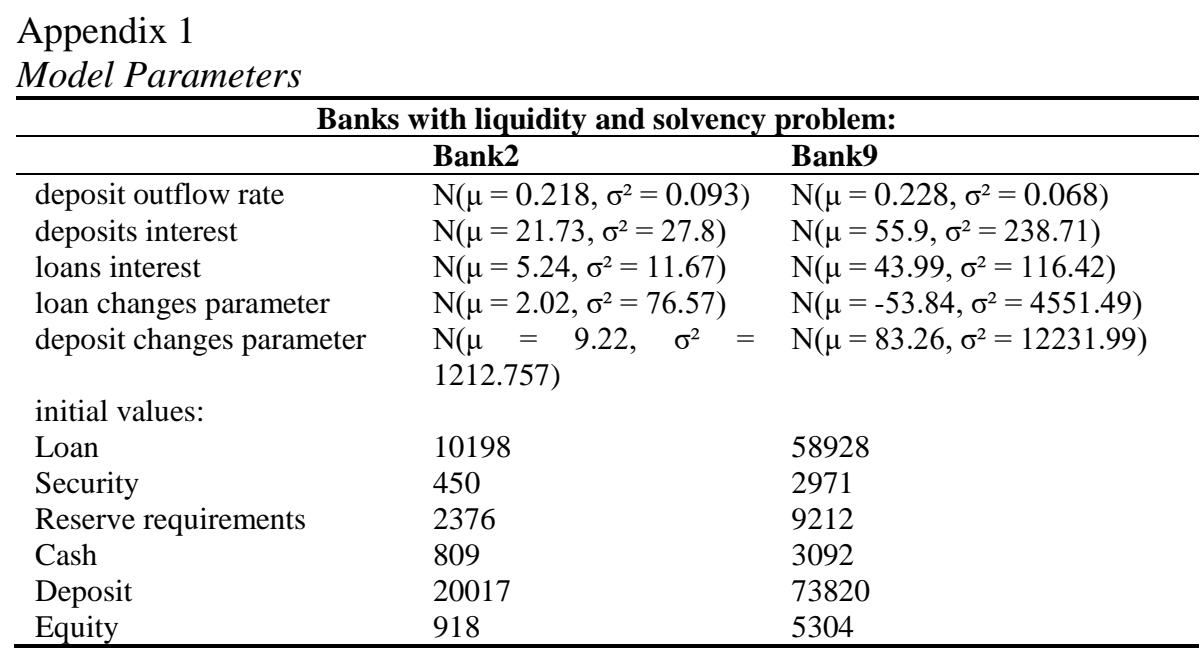

\begin{tabular}{|c|c|c|c|}
\hline \multicolumn{4}{|c|}{ Banks with solvency problem: } \\
\hline & Bank3 & Bank5 & Bank8 \\
\hline deposit outflow rate & $\begin{array}{l}\mathrm{N}\left(\mu=0.29, \sigma^{2}=\right. \\
0.075)\end{array}$ & $\begin{array}{l}\mathrm{N}\left(\mu=0.436, \sigma^{2}=\right. \\
0.063)\end{array}$ & $\begin{array}{l}\mathrm{N}\left(\mu=0.186, \quad \sigma^{2}=\right. \\
0.096)\end{array}$ \\
\hline deposits interest & $\begin{array}{l}\mathrm{N}\left(\mu=18.85, \sigma^{2}=\right. \\
9.3487)\end{array}$ & $\begin{array}{l}\mathrm{N}\left(\mu=64.8, \sigma^{2}=\right. \\
47.39)\end{array}$ & $\mathrm{N}\left(\mu=7.8, \sigma^{2}=3.69\right)$ \\
\hline loans interest & $\begin{array}{l}\mathrm{N}\left(\mu=17.37, \sigma^{2}=\right. \\
24.46)\end{array}$ & $\begin{array}{l}\mathrm{N}\left(\mu=53.56, \sigma^{2}=\right. \\
104.59)\end{array}$ & $\mathrm{N}\left(\mu=13.8, \sigma^{2}=91.17\right)$ \\
\hline $\begin{array}{ll}\text { loan } & \text { changes } \\
\text { parameter }\end{array}$ & $\begin{array}{l}\mathrm{N}\left(\mu=-2.46, \sigma^{2}=\right. \\
523.84)\end{array}$ & $\begin{array}{l}\mathrm{N}\left(\mu=-89.34, \sigma^{2}=\right. \\
3348.84)\end{array}$ & $\begin{array}{l}\mathrm{N}\left(\mu=-15.98, \quad \sigma^{2}=\right. \\
656.8)\end{array}$ \\
\hline $\begin{array}{ll}\text { deposit } & \text { changes } \\
\text { parameter } & \\
\end{array}$ & $\begin{array}{l}\mathrm{N}\left(\mu=28.73, \sigma^{2}=\right. \\
2379.93)\end{array}$ & $\begin{array}{l}\mathrm{N}\left(\mu=183.44, \sigma^{2}=\right. \\
17188.64)\end{array}$ & $\begin{array}{l}\mathrm{N}\left(\mu=14.75, \quad \sigma^{2}=\right. \\
159.95)\end{array}$ \\
\hline \multicolumn{4}{|l|}{ initial values: } \\
\hline Loan & 30329 & 88899 & 9180 \\
\hline Security & 957 & 7842 & 994 \\
\hline $\begin{array}{l}\text { Reserve } \\
\text { requirements }\end{array}$ & 3818 & 17337 & 899 \\
\hline Cash & 1825 & 7248 & 119 \\
\hline Deposit & 34709 & 122799 & 7478 \\
\hline Equity & 2730 & 8001 & 826 \\
\hline
\end{tabular}




\begin{tabular}{|c|c|c|c|}
\hline \multicolumn{4}{|c|}{ Banks with no liquidity and solvency problem: } \\
\hline & Bank1 & Bank4 & Bank6 \\
\hline cash outflow rate & $\begin{array}{l}\mathrm{N}\left(\mu=0.41, \sigma^{2}=\right. \\
0.146)\end{array}$ & $\begin{array}{l}\mathrm{N}\left(\mu=0.48, \sigma^{2}=\right. \\
0.12)\end{array}$ & $\mathrm{N}\left(\mu=0.45, \sigma^{2}=0.145\right)$ \\
\hline deposits interest & $\begin{array}{l}\mathrm{N}\left(\mu=8.6, \sigma^{2}=\right. \\
0.107)\end{array}$ & $\begin{array}{l}\mathrm{N}\left(\mu=63.28, \sigma^{2}=\right. \\
49.70)\end{array}$ & $\begin{array}{l}\mathrm{N}\left(\mu=3.7125, \sigma^{2}=\right. \\
0.21)\end{array}$ \\
\hline loans interest & $\begin{array}{l}\mathrm{N}\left(\mu=10.0083 \sigma^{2}\right. \\
=2.12)\end{array}$ & $\begin{array}{l}\mathrm{N}\left(\mu=69.57, \sigma^{2}=\right. \\
1713.7)\end{array}$ & $\mathrm{N}\left(\mu=6.027, \sigma^{2}=3.21\right)$ \\
\hline $\begin{array}{ll}\text { loan } & \text { changes } \\
\text { parameter } & \\
\end{array}$ & $\begin{array}{l}\mathrm{N}\left(\mu=-6.3, \sigma^{2}=\right. \\
118.32)\end{array}$ & $\begin{array}{l}\mathrm{N}\left(\mu=-105, \sigma^{2}=\right. \\
22165.25)\end{array}$ & $\begin{array}{l}\mathrm{N}\left(\mu=-9.42, \quad \sigma^{2}=\right. \\
410.16)\end{array}$ \\
\hline $\begin{array}{ll}\text { deposit } & \text { changes } \\
\text { parameter } & \\
\end{array}$ & $\begin{array}{l}\mathrm{N}\left(\mu=8.42, \sigma^{2}=\right. \\
294.98)\end{array}$ & $\begin{array}{l}\mathrm{N}\left(\mu=154.59, \sigma^{2}=\right. \\
19269.9)\end{array}$ & $\begin{array}{l}\mathrm{N}\left(\mu=11.28, \quad \sigma^{2}=\right. \\
363.26)\end{array}$ \\
\hline \multicolumn{4}{|l|}{ initial values: } \\
\hline Loan & 13130 & 55840 & 6940 \\
\hline Security & 954 & 3377 & 515 \\
\hline $\begin{array}{l}\text { Reserve } \\
\text { requirements }\end{array}$ & 1736 & 13001 & 790 \\
\hline Cash & 518 & 5337 & 59 \\
\hline Deposit & 16768 & 106923 & 7805 \\
\hline Equity & 1297 & 5026 & 898 \\
\hline
\end{tabular}

\begin{tabular}{|c|c|c|c|c|}
\hline \multicolumn{5}{|c|}{ Banks with no liquidity and solvency problem: } \\
\hline & Bank7 & Bank10 & Bank11 & Bank12 \\
\hline cash outflow rate & $\begin{array}{l}\mathrm{N}\left(\mu \quad 0.62, \quad \sigma^{2}=\right. \\
0.107)\end{array}$ & $\begin{array}{l}\mathrm{N}\left(\mu=0.412, \sigma^{2}=\right. \\
0.174)\end{array}$ & $\begin{array}{l}\mathrm{N}\left(\mu=0.34, \sigma^{2}=\right. \\
0.15)\end{array}$ & $\begin{array}{l}\mathrm{N}\left(\mu=0.55, \sigma^{2}=\right. \\
0.17)\end{array}$ \\
\hline deposits interest & $\begin{array}{l}\mathrm{N}\left(\mu=60.34, \sigma^{2}=\right. \\
18.14)\end{array}$ & $\begin{array}{l}\mathrm{N}\left(\mu=44.68, \sigma^{2}=\right. \\
119.55)\end{array}$ & $\begin{array}{l}\mathrm{N}\left(\mu=7.75, \sigma^{2}=\right. \\
0.21389)\end{array}$ & $\begin{array}{l}\mathrm{N}\left(\mu=2.99, \sigma^{2}=\right. \\
0.52)\end{array}$ \\
\hline loans interest & $\begin{array}{l}\mathrm{N}\left(\mu=85.7, \quad \sigma^{2}=\right. \\
337.17)\end{array}$ & $\begin{array}{l}\mathrm{N}\left(\mu=55.12, \sigma^{2}=\right. \\
280.36)\end{array}$ & $\begin{array}{l}\mathrm{N}\left(\mu=7.38, \sigma^{2}=\right. \\
1.55)\end{array}$ & $\begin{array}{l}\mathrm{N}\left(\mu=4.04, \sigma^{2}=\right. \\
2.31)\end{array}$ \\
\hline $\begin{array}{l}\text { loan changes } \\
\text { parameter }\end{array}$ & $\begin{array}{l}\mathrm{N}\left(\mu=-148.05, \sigma^{2}=\right. \\
34026.14)\end{array}$ & $\begin{array}{l}\mathrm{N}\left(\mu=-90.63, \sigma^{2}=\right. \\
5831.67)\end{array}$ & $\begin{array}{l}\mathrm{N}\left(\mu=-3.49, \sigma^{2}=\right. \\
86.13)\end{array}$ & $\begin{array}{l}\mathrm{N}\left(\mu=-10.32, \sigma^{2}\right. \\
=181.95)\end{array}$ \\
\hline $\begin{array}{l}\text { deposit changes } \\
\text { parameter }\end{array}$ & $\begin{array}{l}\mathrm{N}\left(\mu=167.35, \sigma^{2}=\right. \\
81592.33)\end{array}$ & $\begin{array}{l}\mathrm{N}\left(\mu=107.64, \sigma^{2}=\right. \\
12822.64)\end{array}$ & $\begin{array}{l}\mathrm{N}\left(\mu=8.76, \sigma^{2}=\right. \\
160.94)\end{array}$ & $\begin{array}{l}\mathrm{N}\left(\mu=11.2, \sigma^{2}=\right. \\
154.92)\end{array}$ \\
\hline \multicolumn{5}{|l|}{ initial values: } \\
\hline Loan & 146289 & 60753.216 & 11249 & 5229 \\
\hline Security & 10514 & 3186 & 493 & 274 \\
\hline $\begin{array}{l}\text { Reserve } \\
\text { requirements }\end{array}$ & 24053 & 7147 & 1531 & 636 \\
\hline Cash & 14104 & 7459 & 721 & 576 \\
\hline Deposit & 143885 & 66231.5195 & 13661 & 5719 \\
\hline Equity & 13166 & 7711 & 1327 & 471 \\
\hline
\end{tabular}

